\title{
UPAYA MENINGKATKAN PRESTASI BELAJAR DENGAN MODEL PEMBELAJARAN KOOPERATIF TIPE $J I G S A W$ PADA MATA PELAJARAN IPS SISWA KELAS III MIN NGESTIHARJO
}

\author{
Sukati \\ PGMI STIA Alma Ata Yogyakarta \\ Email : kanza@gmail.com
}

\begin{abstract}
Abstraks
Jenis penelitian ini adalab Penelitian Tindakan Kelas (PTK). Subyek penelitian ini adalah siswa kelas III MIN Ngestiharjo, Wates, Kulon Progo, 40 mahasiswa pada semester kedua tabun akademik 2013/2014. Objek penelitian ini adalab aktivitas yang terjadi di dalam kelas selama proses pembelajaran. CAR ini dilakukan dengan dua siklus, setiap siklus terdiri dari satu pertemuan. Data diperoleb dari observasi, wawancara, hasil tes dan dokumentasi. Data dianalisis dengan deskriptif kualitatif melalui beberapa tahapan analisis data pelaksanaan pembelajaran, siswa analisis data prestasi untuk menggambarkan aktivitas siswa dan kesimpulan. Validitas data dilakukan dengan meminta pendapat dari para abli (expert judgement).

Hasil penelitian menunjukkan babwa dengan menggunakan model pembelajaran kooperatif jigsaw, pembelajaran berlangsung lancar dengan menggunakan lima tahap jigsaw koperasi yang dibaca, diskusi kelompok abli, laporan kelompok, tes dan kelompok penghargaan. Berdasarkan analisis model yang dapat meningkatkan prestasi belajar siswa. Meningkatkan prestasi belajar dapat dibuktikan oleh hasil evaluasi pembelajaran IPS (IPS). Sebelum menerapkan CAR, persentase siswa yang mendapatkan di atas 50\% setelah KKM diimplementasikan oleh class action jigsaw model pembelajaran kooperatif meningkat menjadi 78,6\%. Pada siklus II hasil tes pra menunjukkan babwa persentase siswa yang mendapatkan nilai lebib dari KKM adalab 64,3\% setelab aksi itu kemudian meningkat menjadi 92,9\%.
\end{abstract}

Kata kunci: Jigsaw Model, prestasi siswa.

\section{Abstract}

The type of this research is the Classroom Action Research (CAR). The subjects of this study were students of grade III MIN Ngestiharjo, Wates, Kulon Progo, 
40 students in the second semester of the academic year 2013/2014. The object of the study is activities that occur in the classroom during the learning process. This CAR is done by two cycles, each cycle consisting of one meeting. Data were obtained from the observation, interviewes, test results and documentation. The data were analyzed with descriptive qualitative through several stages of data analysis of implementation of learning, student achievement data analysis to describe the activities of students and conclusion. The validity of the data is done by asking the opinion of the experts (expert judgment).

The results showed that by using a jigsaw cooperative learning model, the learning takes place smoothly by using a five-stage cooperative jigsaw that is read, the expert group discussions, group reports, tests and awards groups. Based on the analysis that model can improve student achievement. Improving learning achievements can be proved by the results of the evaluation of learning social studies (IPS). Before implementing the CAR, the percentage of students who get above 50\% after the KKM is implemented by a class action jigsaw cooperative learning model increased to $78.6 \%$. In the second cycle of pre test results showed that the percentage of students who get more value from KKM was $64.3 \%$ after the action was later increased to $92.9 \%$.

Keyword: Jigsaw Model, student's achievement.

\section{PENDAHULUAN}

Pendidikan merupakan suatu proses mencerdaskan kehidupan bangsa, meningkatkan kualitas manusia Indonesia, serta mewujudkan tujuan nasional bangsa Indonesia. Undang-undang No. 20 Tahun 2003 tentang sistem pendidikan nasional menyatakan bahwa pendidikan adalah usaha sadar dan terencana untuk mewujudkan suasana belajar dan proses pembelajaran agar peserta didik secara aktif mengembangkan potensi dirinya untuk memiliki kekuatan spiritual keagamaan, pengendalian diri, kepribadian, kecerdasan, akhlak mulia, serta keterampilan yang diperlukan dirinya, masyarakat, bangsa dan Negara. ${ }^{1}$

Proses pendidikan yang dilakukan di sekolah merupakan kegiatan pendidikan belajar dan mengajar, untuk mencapai tujuan pendidikan adalah salah satu tanggung jawab dan beban semua pihak yang bergerak dalam dunia pendidikan untuk merealisasikan peningkatan mutu pendidikan. Salah satu usaha untuk meningkatkan mutu pendidikan yaitu melalui kualitas pengajaran

${ }^{1}$ Wina Sanjaya, Strategi Pembelajaran Berorientasi Standar Proses Pendidikan (Jakarta:Kencana Prenada Media, 2006), hlm. 2 
dari masing-masing mata pelajaran, keberhasilan peserta didik dalam mencapai tujuan pendidikan tergantung dari proses belajar yang dialami oleh peserta didik, selain itu dalam proses belajar dan mengajar dituntut suatu perencanaan yang cukup mantap dari guru.

Model pembelajaran ialah pola yang digunakan sebagai pedoman dalam merencanakan pembelajaran di kelas maupun tutorial. ${ }^{2}$ Proses pembelajaran yang dilakukan oleh banyak tenaga pendidik saat ini cenderung pada pencapaian target materi kurikulum, lebih mementingkan pada penghafalan konsep bukan pada pemahaman. Hal ini dapat dilihat dari kegiatan pembelajaran dalam kelas yang selalu didominasi oleh guru, dengan demikian suasana pembelajaran menjadi tidak kondusif sehingga siswa menjadi pasif.

Kooperatif tipe jigsaw merupakan model pembelajaran kooperatif dimana siswa belajar dalam kelompok kecil yang terdiri dari 4-5 orang dengan karakteristik yang heterogen dan setiap anggota bertanggung jawab untuk mempelajari masalah tertentu dari masalah yang diberikan dan menyampaikan materi tersebut kepada anggota kelompok yang lain. ${ }^{3}$

Model pembelajaran di kelas yang semula hanya konvensional secara monoton dan guru sebagai pusat pembelajaran. Hal ini sudah tidak sesuai dengan perubahan paradigma pendidikan yang semula teacher centre berubah menjadi student centre. Perubahan ini tidak hanya membawa dampak terhadap metode, aktivitas dan sikap ilmiah belajar siswa, akan tetapi juga terhadap cara penilaian yang berpusat pada peserta didik.

Upaya untuk meningkatkan prestasi siswa guru harus lebih kreatif dan membuat pembelajaran dengan lebih menarik dan disukai oleh peserta didik. Pembelajaran kooperatif terutama tipe Jigsaw dianggap cocok diterapkan dalam pendidikan di Indonesia karena sesuai dengan budaya bangsa Indonesia yang menjunjung tinggi nilai kerja sama. Penggunaan model kooperatif mempunyai tujuan agar siswa mampu bekerja sama dalam kelompok dengan teman yang lain dalam mencapai tujuan bersama. ${ }^{4}$ Metode pembelajaran kerja sama distruktur sedemikian rupa sehingga masing-masing anggota dalam satu kelompok melaksanakan tanggung jawab pribadinya karena ada sistem akuntabilitas individu. Siswa tidak bisa begitu saja membonceng jerih payah rekannya dan usaha setiap siswa akan dihargai sesuai dengan poin-poin perbaikannya.

${ }^{2}$ Agus Suprijono, Cooperative Learning ( Surabaya:Pustaka Pelajar, 2011), hlm. 46 ${ }^{3}$ Nurhadi, Kurikulum 2004 (Jakarta: Grasindo, 2004), hlm.117

${ }^{4}$ Roestiyah, Strategi Belajar Mengajar,(Jakarta: PT Rineka Cipta, 2006), hlm. 15 
Keadaan pembelajaran yang ada di MIN Ngestiharjo kususnya pada mata pelajaran IPS kelas III masih dapat dikatakan belum berhasil, hal ini dapat dilihat ketika pembelajaran berlangsung siswa masih pasif, bahkan sering kali siswa hanya bermain-main dan berlari-lari saat pembelajaran berlangsung. Menurut penuturan Ibu Rohayati Latifah S.Pd.I sebagai guru kelas III MIN Ngestiharjo, beliau mengajar anak masih terpacu pada buku paket dan hanya sering menggunakan metode ceramah, pernah juga menggunakan metode diskusi namun itu hanya pada pokok bahasan tertentu saja. Penggunaan medianya terbatas menggunakan buku paket dan papan tulis, pembelajaran IPS kelas III yang terjadi di MIN Ngestiharjo memiliki beberapa kendala, diantaranya susahnya mengatur anak, anak kurang aktif bahkan nilai pelajaran IPS masih banyak yang dibawah KKM (Kreteria Ketuntasan Minimum), sedangkan nilai KKM untuk pelajaran IPS sendiri adalah $65 .^{5}$

Berdasarkan pengamatan yang peneliti lakukan pada hari jum'at 08 November 2013, pada mata pelajaran IPS kelas III MIN Ngestiharjo yang berjumlah tiga belas orang, prestasi belajarnya masih rendah. Hal ini terlihat dari hasil UTS (Ulangan Tengah Semester) yang sebagian masih dibawah KKM Dari semua siswa yang mengikuti UTS hanya 38,46\% yang nilainya di atas KKM. Hal tersebut menunjukkan bahwa siswa kurang menemukan makna dari materi yang mereka pelajari serta sesuatu yang menyenangkan dalam pembelajaran.

Berdasarkan uraian masalah tersebut diatas, maka masalah yang dikaji dalam penelitian ini adalah Bagaimana pelaksanaan pembelajaran IPS kelas III MIN Ngestiharjo dengan model pembelajaran kooperatif tipe jigsaw dan apakah model pembelajaran kooperatif tipe jigsaw dapat meningkatkan prestasi belajar pada mata pelajaran IPS siswa kelas III MIN Ngestiharjo?

\section{METODE}

Jenis penelitian ini merupakan penelitian tindakan kelas yaitu dengan menggunakan model pembelajaran kooperatif tipe jigsaw sedangkan desain penelitian tindakan kelas melalui empat tahapan diantaranya perencanaan, pelaksanaan, pengamatan dan reflesksi. Berikut ini adalah gambar model PTK: ${ }^{6}$

${ }^{5}$ Rohayati Latifah, Wali kelas III MIN Ngestiharjo, Wawancara Tanggal 08 November 2013.

${ }^{6}$ Suharsimi Arikunto dkk, Penelitian Tindakan Kelas (Jakarta:PT Bumi Aksara, 2008 cet. Ke Enam), hlm. 3 


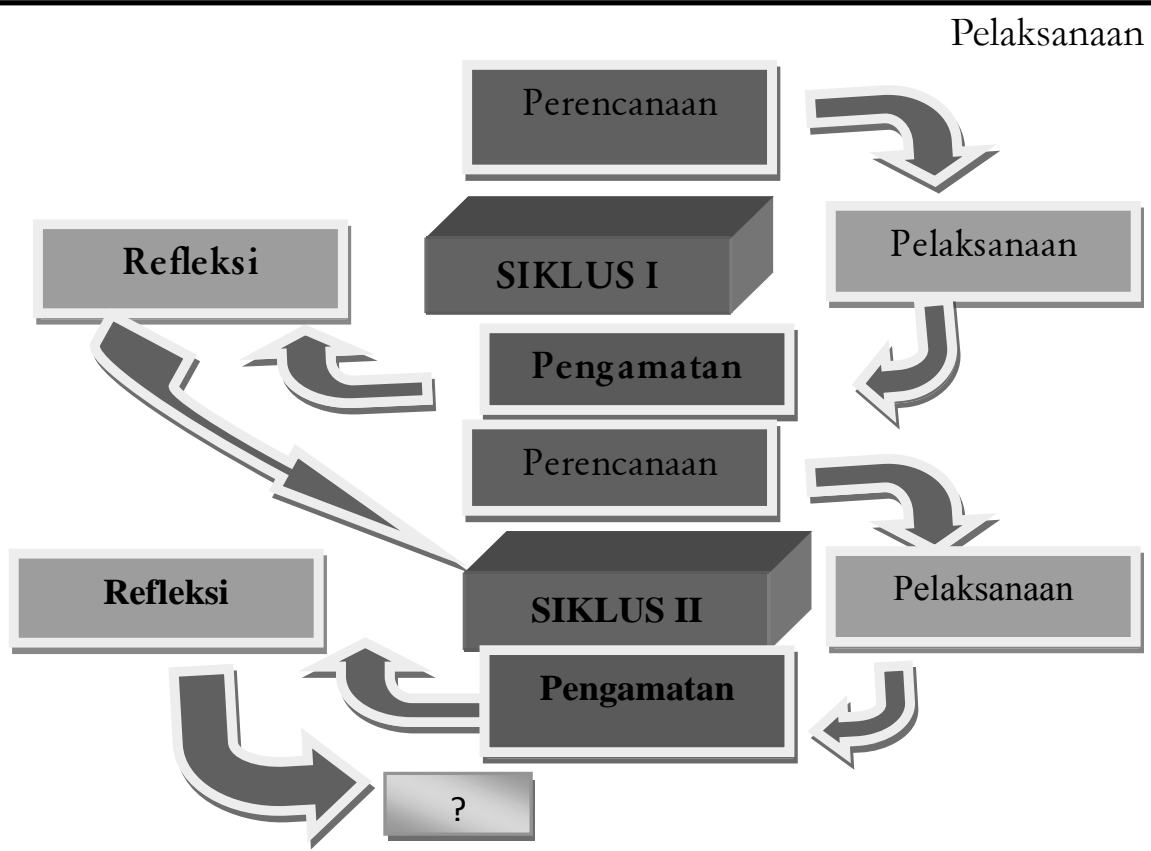

Gambar 6. Model Penelitian Tindakan Kelas

Populasi penelitian ini yaitu seluruh siwa kelas III MIN Ngestiharjo yang berjumlah 14 orang pada semester genap tahun ajaran 2013/2014. Teknik pengumpulan data pada penelitian ini adalah dengan metode observasi, wawancara, tes dan dokumentasi. Instrumen penelitian yang digunakan adalah pedoman observasi, pedoman wawancara, RPP dan silabus, soal pre test dan post test, soal tes kelompok, dan pedoman dokumentasi. Validitas yang digunakan dalam penelitian ini adalah validitas isi. Menurut Anas, validitas isi adalah validitas yang ditilik dari segi isi tes itu sendiri sebagai alat pengukur hasil belajar. Instrumen lembar observasi dikonsultasikan dengan guru kelas dan pembimbing. ${ }^{7}$.

Untuk mengetahi hasil peningkatan prestasi belajar dapat diketahui apabila nilai rata-rata post test lebih besar daripada nilai rata-rata pre test. Nilai prestasi belajar pada siklus I dan siklus II dipresentasikan kemudian dibandingkan dengan menggunakan rumus:

$$
\mathrm{P}=\frac{f}{N} \frac{f}{N} \times 100 \%
$$
hlm. 164

${ }^{7}$ Anas Sudijono, Statistik Pendidikan (Jakarta:PT Raja Grafindo Persada, 1995), 
Keterangan:

$f$ : Frekuensi yang sedang dicari persentasenya

$\mathrm{N}$ : Number of Cases (jumlah frekuensi/banyaknya individu)

$\mathrm{p}$ : Angka persentase ${ }^{8}$

Teknik analisis data dengan menggunakan metode analisis kualitatif yaitu dengan langkah-langkah analisis data pelaksanaan pembelajaran, analisis prestasi belajar siswa, analisis data untuk mendeskripsikan aktivitas siswa, penarikan kesimpulan. Untuk mengetahui keberhasilan Penelitian Tindakan Kelas ini peneliti menetapkan indikator kinerja sebagai berikut: Pertama, pembelajaran dengan menggunakan model kooperatif tipe jigsaw berjalan dengan lancar dengan menggunakan lima langkah pembelajaran kooperatif tipe jigsaw yaitu, membaca, diskusi kelompok ahli, laporan kelompok, tes, dan penghargaan kelompok. Kedua, rata-rata nilai tes hasil belajar siswa pada mata pelajaran IPS di atas nilai KKM yaitu 65. Ketiga, siswa yang mendapat nilai diatas KKM minimal $70 \%$.

\section{HASIL PENELITIAN}

Pelaksanaan tindakan dalam penelitian tindakan kelas ini dilaksanakan atas observasi pembelajaran sebelum menggunakan model pembelajaran kooperatif tipe jigsaw. Permasalahan yang terjadi dalam proses pembelajaran dijadikan acuan untuk merencanakan kegiatan yang akan digunakan dalam menyelesaikan masalah tersebut.

Hasil observasi dan wawancara yang dilakukan peneliti sebelum dilaksanakan tindakan pada tanggal 08 November 2013 antara lain ketika pembelajaran berlangsung siswa masih pasif, bahkan sering kali siswa hanya bermain-main dan berlari-lari saat pembelajaran berlangsung. Guru mengajar anak masih terpacu pada buku paket dan hanya sering menggunakan metode ceramah, pernah juga menggunakan metode diskusi namun itu hanya pada pokok bahasan tertentu saja. Penggunaan medianya terbatas menggunakan buku paket dan papan tulis.

Pelaksanaan tindakan selama dua siklus dengan dua pertemuan dilakukan oleh peneliti dan guru kelas sebagai kolaborator. Penelitian dilakukan II siklus karena sudah mendapatkan hasil penelitian yang sesuai dengan indikator yaitu pembelajaran dengan menggunakan model kooperatif tipe jigsaw berjalan dengan lancar, rata-rata nilai tes hasil belajar siswa pada mata pelajaran IPS di hlm. 43

${ }^{8}$ Anas Sudijono, Pengantar Statistik Pendidikan (Jakarta:Raja Grafindo, 2008), 
atas nilai KKM yaitu 65 dan siswa yang mendapat nilai diatas KKM minimal 70\% maka penelitian dicukupkan sampai siklus II.

Proses Pembelajaran IPS Dengan Menggunakan Model Kooperatif Tipe Jigsaw:

Proses pembelajaran dengan menggunakan model kooperatif tipe jigsaw pada mata pelajaran IPS siswa kelas III MIN Ngestiharjo diawali dengan proses pembelajaran yang belum maksimal, kemudian pada pertemuan dua proses belajar mengajar dapat dikatakan sudah maksimal, hal tersebut didukung dengan meningkatnya keaktifan siswa dalam proses belajar hingga prestasi belajar siswa meningkat hampir 100\%. Berikut ini dijabarkan proses pembelajaran dengan menggunakan model kooperatif tipe jigsaw:

\section{Membaca}

Pada siklus I dan siklus II peneliti melakukan langkah awal pembelajaran dengan membagikan materi kepada masing-masing peserta didik dimana setiap peserta didik dalam satu kelompok mendapatkan materi yang berbeda, kemudian siswa ditugaskan membaca dan memahami masing-masing materi yang ditugaskan. Dalam waktu kurang lebih 10 menit semua siswa selesai membaca dan memahami materi.

\section{Diskusi kelompok ahli}

Pada tahap ini setiap siswa yang mendapatkan materi sama bertemu dalam satu kelompok, adapun materi dalam masing-masing kelompok ahli adalah, jenis-jenis pekerjaan di masyarakat, pekerjaan yang menghasilkan jasa, dan jenis pekerjaan yang menghasilkan barang. Peserta didik dengan materi yang sama bertemu untuk mendiskusikannya dalam kelompok ahli. Dalam kelompok ini siswa mendiskusikan materi dan bagaimana cara penyampaikan materi tersebut kepada teman-teman yang ada pada kelompok asal.

\section{Laporan kelompok}

Pada tahap laporan kelompok, semua siswa yang telah selesai berdiskusi pada kelompok ahli kemudian para ahli kembali ke kelompok asalnya untuk mengajarkan teman kelompok asal mereka mengenai topik ahli. Pada kelompok asal ini siswa secara bergantian menjelaskan tentang materi yang sudah dibahas pada kelompok ahli, siswa saling bertanya jawab mengenai materi-materi yang belum mereka pahami. 


\section{Tes}

Peneliti memberikan dua jenis soal tes, yaitu tes individu dan kelompok, semua soal-soal yang diberikan berlandaskan pada indikator keberhasilan yang telah ditentukan. Peserta didik mengerjakan tes secara individu dimana soal tersebut mencangkup seluruh topik yang telah dipelajari dan didiskusikan. Pada pelaksanaan tes individu semua siswa dituntut untuk dapat mengerjakan soal secara mandiri, jumlah soal tes individu ini adalah 10 soal pilihan ganda. Sedangkan soal tes kelompok terdiri dari 9 soal yang akan diperebutkan oleh 4 kelompok. Soal tes yang berbentuk permainan ini menggunakan media kertas manila, lem, lidi, double tip dll. Dalam permainan model kuis ini setiap kelompok dituntut untuk aktif dan memperjuangkan teman sekelompoknya dengan kerja sama menjawab soal-soal kuis yang disediakan hingga mendapat skor tertinggi.

\section{Penghargaan kelompok}

Penghargaan kelompok akan diberikan kepada kelompok yang memiliki skor paling tinggi, kelompok yang memiliki skor tinggi yaitu kelompok yang mampu menjawab semua pertanyaan dalam kuis dengan benar. Pada siklus I penghargaan diberikan kepada kelompok 2 yang dapat mengumpulkan skor yang paling tinggi. Sedangkan pada siklus II kelompok yang mendapat penghargaan adalah kelompok III dengan kriteria kelompok yang aktif dalam permainan dan mendapat skor banyak. Penghargaan kelompok ini berbentuk peralatan sekolah seperti, pensil, buku, bolpoin dan penghapus. Penghargaan diberikan pada akhir pembelajaran.

Peningkatan Prestasi Belajar Mata Pelajaran IPS Kelas III dengan Menggunakan Model Pembelajaran Kooperatif Tipe Jigsaw

\section{Siklus I}

Hasil penelitian pada siklus I menunjukkan peningkatan prestasi belajar sebelum dikenai tindakan. Hal ini dapat ditunjukkan dengan peningkatan nilai rata-rata yang semula sebelum dikenai tindakan adalah 64,29 kemudian setelah dikenai tindakan dengan model pembelajaran kooperatif tipe jigsaw nilai ratarata menjadi 74,28 dengan persentase siswa yang mendapat nilai di atas KKM sejumlah $78,6 \%$.

Dalam siklus I ini masih ada beberapa siswa yang belum mampu melampaui KKM (nilai $\geq 65,00$ ) hal ini bisa disebabkan oleh kurang jelasnya siswa saat menerima penjelasan tentang model pembelajaran kooperatif tipe jigsaw yang masih terasa asing bagi siswa. 
Berdasarkan penjelasan dari guru kelas, selama ini siswa kelas III MIN Ngestiharjo belum pernah melakukan pembelajaran dengan model ini. Jadi model pembelajaran kooperatif tipe jigsaw termasuk model baru bagi mereka dan siswa belum paham tentang tahapan yang harus dilakukan selama proses pembelajaran.

Dalam proses pembelajaran siswa merasa bingung saat mengikuti langkah-langkah dalam pelaksanaan pembelajaran dengan menggunakan model kooperatif tipe jigsaw yang cukup rumit. Seharusnya guru terlebih dahulu memperkenalakan model ini kepada siswa sebelum penelitian, agar siswa dapat langsung memposisikan diri dan tahu apa yang harus dilakukan.

Peningkatan yang terjadi pada siklus I sudah dapat dikatakan berhasil karena persentase siswa yang mendapat nilai di atas KKM sudah mencapai 70\%, namun untuk memperoleh hasil yang lebih maksimal peneliti dan guru kelas sepakat untuk berusaha melakukan perbaikan dengan memberikan penjelasan yang lebih detail mengenai alur model pembelajaran kooperatif tipe jigsaw pada awal pembelajaran siklus II. Peneliti juga lebih serius mengawasi agar siswa dapat memanfaatkan waktu dengan optimal untuk berinteraksi.

\section{Siklus II}

Pada siklus II ini juga terjadi peningkatan prestasi belajar dibandingkan dengan siklus I. Hal ini dapat dilihat dari peningkatan rata-rata siswa pada siklus I yang semula 74,28 menjadi 77,85 pada siklus II dengan kreteria keberhasilan $92,9 \%$ yang telah melampaui target yang telah ditetapkan oleh peneliti yaitu 70\% dan melampaui persentase pada siklus I. Maka siklus II ini tidak dilanjutkan ke siklus III karena peneliti sudah cukup puas dengan hasil yang ada walaupun belum 100\% siswa yang mampu melampaui KKM (nilai 65,00).

Pelaksanaan pembelajaran dengan menggunakan model pembelajaran kooperatif tipe jigsaw baik siklus I maupun siklus II sudah membuat siswa aktif dan peningkatan prestasi belajar siswa. Dengan keadaan siswa yang lebih aktif maka pembelajaran menjadi tidak membosankan dan informasi yang digali oleh siswa menjadi lebih banyak.

Dalam siklus II ini terdapat 1 siswa (7,1\%) yang belum mampu melampaui nilai 65,00. Dugaan peneliti, hal ini dikarenakan keterbatasan waktu yang ada. Siswa yang lambat dalam menggali informasi akan sulit untuk memperoleh informasi yang diperlukan karena mereka tidak punya cukup waktu. Hasilnya ketika evaluasi diadakan, maka siswa tersebut kesulitan dalam mengerjakan soal dan hasilnya tidak sesuai dengan yang diharapkan. 
Namun secara garis besar penerapan model pembelajaran kooperatif tipe jigsaw dapat meningkatkan prestasi belajar siswa, karena dengan proses penggalian informasi yang dilakukan sendiri oleh siswa sehingga siswa menjadi lebih aktif dan pembelajaran menjadi lebih bermakna. Guru hanya sebagai fasilitator dan pemberi pengarahan kepada siswa dalam melakukan kegiatan. Berdasarkan hasil pelaksanaan tindakan pada siklus I dan II dapat dinyatakan bahwa terjadi peningkatan prestasi belajar IPS dengan penggunaan model pembelajaran kooperatif tipe jigsaw dari siklus I ke siklus II. Hal tersebut dapat dilihat dari tabel berikut

Tabel 1. Daftar Nilai Siklus I dan II

\begin{tabular}{clcccc}
\hline \multirow{2}{*}{ NO NAMA } & \multicolumn{2}{c}{ Siklus I } & \multicolumn{2}{c}{ Siklus II } \\
\cline { 3 - 6 } & & Pre Test & Post Test & Pre Test & Post Test \\
\hline 1 & Andi Nur Saputro & 70 & 70 & 50 & 70 \\
2 & Hasna Abidah Sholehah & 80 & 50 & 60 \\
3 & Fauziyah Nur Khasanah & 80 & 60 & 50 & 70 \\
4 & Kanaka Maritza & 70 & 80 & 70 & 80 \\
5 & Khaidar Fajar Nur Syarif & 60 & 90 & 60 & 70 \\
6 & Muh Misbahul Munir & 60 & 60 & 80 & 80 \\
7 & Noorazharul L & 80 & 70 & 70 & 90 \\
8 & Nugie Al-afghani & 70 & 70 & 80 & 70 \\
9 & Rizki Dwi Ramadhan & 70 & 80 & 70 & 90 \\
10 & Roman Zakia & 40 & 80 & 70 & 80 \\
11 & Shofwan Wifaqurrohman & 60 & 70 & 80 & 100 \\
12 & Tsamarah Jihan & 80 & 90 & 60 & 70 \\
13 & Wardani Febri Kusuma & 50 & 60 & 70 & 80 \\
14 & Wakhidatun Cahya K & 60 & 80 & 70 & 80 \\
\hline & Jumlah & 900 & 1040 & 930 & 1090 \\
\hline & Rata-rata & 64,29 & 74,28 & 66,42 & 77,85 \\
\hline
\end{tabular}

Tabel 2 Distribusi Frekuensi Relatif (Distribusi Persentase) Siklus I dan II

\begin{tabular}{ccccccc}
\hline \multirow{2}{*}{ No } & \multirow{2}{*}{ Nilai } & Frekuensi & \multicolumn{3}{c}{ Persentase $\%$} & \multirow{2}{*}{ Klasifikasi } \\
\cline { 3 - 6 } & & Siklus I & Siklus II & Siklus I & Siklus II & \\
\hline 1 & $0-39,9$ & - & - & - & - & Sangat kurang \\
2 & $40,0-54,9$ & - & - & - & - & Kurang \\
3 & $55,0-69,9$ & 3 & 1 & 21,4 & 7,1 & Cukup \\
4 & $70,0-84,5$ & 9 & 10 & 64,3 & 71,5 & Baik \\
5 & $85,0-100$ & 2 & 3 & 14,3 & 21,4 & Sangat Baik \\
\hline Jumlah & & 14 & 14 & 100 & 100 & \\
\hline Belum & $\leq 64$ & 3 & 1 & $21,4 \%$ & $7,1 \%$ & \\
Tuntas & & & & & & \\
\hline Tuntas & $\geq 65$ & 11 & 13 & $78,6 \%$ & $92,9 \%$ & \\
\hline
\end{tabular}




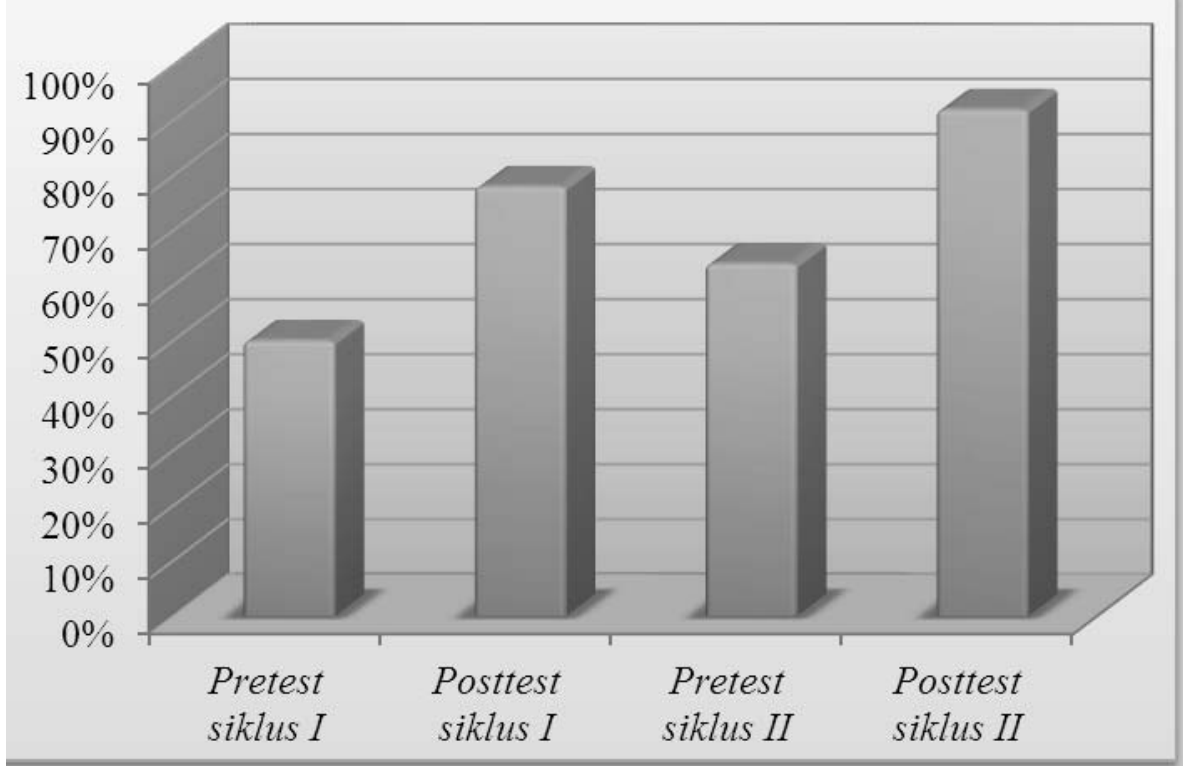

Gambar 11. Persentase Kenaikan Prestasi Siswa Siklus I dan II

Dari tabel distribusi persentase di atas apabila dikonsultasikan dengan tabel konversi persentase belajar siswa, maka dapat dijelaskan bahwa pada pembelajaran sebelum tindakan diperoleh 7 siswa mendapat kategori nilai baik, sedangkan 7 siswa lain mendapat kategori nilai cukup bahkan ada yang kurang. Setelah dilakukan tindakan siklus I kategori nilai baik meningkat menjadi 9 siswa mendapat kategori nilai baik dan 2 orang mendapat kategori nilai baik sekali dengan kategori 3 siswa mendapat nilai kurang. Pada siklus II meningkat lagi menjadi 10 orang mendapat kategori nilai baik, 3 orang mendapat nilai baik sekali dan 1 orang yang mendapat kategori kurang.

Upaya meningkatkan prestasi belajar dengan menggunakan model pembelajaran kooperatif tipe jigsaw pada siswa kelas III MIN Ngestiharjo dilaksanakan dalam II siklus. Sebagai tolak ukur keberhasilan tindakan adalah dengan siswa yang mendapatkan nilai rata-rata nilai tes hasil belajar siswa pada mata pelajaran IPS di atas nilai KKM yaitu 65 diatas dan siswa yang mendapat nilai di atas KKM minimal 70\%. Selanjutnya pada gambar diatas dapat dilihat bahwa pembelajaran IPS sebelum dilakukan tindakan siklus I persentase siswa yang nilainya di atas KKM adalah 50\% setelah dilaksanakan tindakan kelas dengan model pembelajaran kooperatif tipe jigsaw meningkat menjadi 78,6\%. Pada siklus II hasil pre test menunjukkan bahawa persentase siswa yang mendapatkan nilai lebih dari KKM adalah 64,3\% setelah dilakukan tindakan kemudian meningkat menjadi 92,9\%. Peningkatan persentase nilai 
ini mencerminkan peningkatan prestasi belajar masing-masing siswa sebelum melaksanakan tindakan dan sesudah dilaksanakan tindakan.

Pembelajaran dengan menggunakan model pembelajaran kooperatif tipe jigsaw membuat siswa mampu meningkatkan keberanian dalam mengemukakan pendapatnya serta membangun kerjasama, memahami perbedaan pendapat antar teman, dan menambah semangat belajar sehingga siswa dapat lebih memahami materi yang dipelajari yang pada akhirnya dapat meningkatkan prestasi belajar siswa.

\section{KESIMPULAN}

Model pembelajaran kooperatif tipe jigsaw yang diterapkan pada mata pelajaran IPS siswa kelas III MIN Ngestiharjo berjalan dengan lancar dengan menggunakan lima langkah pembelajaran kooperatif tipe jigsaw yaitu membaca, diskusi kelompok ahli, laporan kelompok, tes dan penghargaan kelompok.

Berdasarkan hasil analisis bahwa pembelajaran dengan model kooperatif tipe jigsaw dapat meningkatkan prestasi belajar siswa kelas III MIN Ngestiharjo, hal ini dapat dibuktikan dari persentase siswa yang mendapatkan nilai di atas KKM sebelum dilaksanakan tindakan sebesar $50 \%$, setelah dilaksanakan tindakan siklus I maka persentase siswa yang mendapat nilai di atas KKM meningkat menjadi 78,6\%. Pada pre test siklus II persentase siswa yang mendapatkan nilai di atas KKM adalah 64,3\% setelah dilakukan tindakan siklus II meningkat menjadi 92,9\%, maka dapat dikatakan prestasi belajar siswa kelas III MIN Ngestiharjo meningkat setelah diberikan tindakan dengan model pembelajaran kooperatif tipe jigsaw.

\section{DAFTAR PUSTAKA}

Agus Suprijono, 2011. Cooperative Learning, Surabaya:Pustaka Pelajar.

Anas Sudijono, 1995. Statistik Pendidikan. Jakarta: PT Raja Grafindo Persada. , 2008. Pengantar Statistik Pendidikan. Jakarta: Raja Grafindo

Nurhadi, 2004. Kurikulum 2004, Jakarta: Grasindo.

Roestiyah, 2006. Strategi Belajar Mengajar, Jakarta: PT Rineka Cipta.

Rohayati Latifah, Wali kelas 3 MIN Ngestiharjo, wawancara tanggal 08 November 2013.

Suharsimi Arikunto, dkk., 2008. cet.ke 6. Penelitian Tindakan Kelas, Jakarta: PT Bumi Aksara.

Wina Sanjaya, 2006. Strategi Pembelajaran Berorientasi Standar Proses Pendidikan, Jakarta: Kencana Prenada Media. 